\title{
DAMPAK PELAKSANAAN PROGRAM PENGEMBANGAN USAHA AGRIBISNIS PEDESAAN (PUAP) DI KABUPATEN INDRAGIRI HULU
}

\author{
Sri Ayu Kurniati \\ Fakultas Pertanian Universitas Islam Riau Jl. Kaharuddin Nasution No. 113 Pekanbaru \\ 28284 \\ Email: sriayukurniati@agr.uir.ac.id
}

\begin{abstract}
ABSTRAK
Kelembagaan pertanian di pedesaan perlu diperkuat oleh peran dari gapoktan untuk mengurangi tingkat kemiskinan dan menciptakan lapangan pekerjaan di pedesaan. Tujuan penelitian ini adalah: 1) Mengidentifikasi karakteristik petani, 2) Mengetahui pelaksanaan program PUAP, 3) Menganalisis kinerja gapoktan, dan 4) Menganalisis dampak kegiatan program PUAP terhadap peningkatan pendapatan petani. Penelitian menggunakan metode survei pada 3 kecamatan yaitu Kecamatan Rengat, Kecamatan Batang Cenaku, dan Kecamatan Pasir Penyu di Kabupaten Indragiri Hulu. Hasil penelitian memperlihatkan petani penerima dana BLM PUAP dalam kategori tenaga kerja produktif, rata-rata berpendidikan rendah, sangat paham dengan segala aktivitas dalam usahataninya, jumlah anggota keluarga rata-rata 4 jiwa, dominan usaha perkebunan kelapa sawit dengan ratarata luas lahan sempit, dan status kepemilikan lahan adalah milik sendiri. Struktur kepengurusan organisasi gapoktan terdiri dari ketua, sekretaris dan bendahara, Analisis kinerja gapoktan dengan metode IPA (Importance Performance Analysis) menyatakan pada kuadran A tingkat kepuasan responden masih sangat rendah, kuadran B tingkat kepuasan relatif lebih tinggi, kuadran $\mathrm{C}$ gapoktan mengadakan kerjasama keuangan, dan kuadran D tidak terdapat variabel yang dinilai memiliki tingkat kepentingan rendah dengan tingkat kinerja tinggi. Sementara hasil uji tstatistik menyatakan terdapat perbedaan yang nyata antara pendapatan sebelum dan sesudah dilaksanakannya program PUAP.
\end{abstract}

Kata kunci: Program PUAP, kelembagaan tani, gapoktan

\section{PENDAHULUAN}

Kemiskinan di pedesaan merupakan masalah nasional yang harus diprioritaskan dalam pembangunan ekonomi berbasis pertanian karena secara langsung maupun tidak langsung akan berdampak pada pengurangan jumlah penduduk miskin (Suprapto, 2008). Permasalahan klasik yang paling sering didengungkan oleh petani adalah ketidakmampuan dalam pembiayaan dan mengakses sumber-sumber permodalan. Banyaknya program pengentasan kemiskinan yang telah dilakukan oleh pemerintah sering kali diterima oleh penerima yang tidak seharusnya. Pemerintah membentuk program Pengembangan Usaha Agribisnis Pedesaan (PUAP) sebagai terobosan untuk menanggulangi kemiskinan dan penciptaan lapangan kerja, mengurangi kesenjangan pembangunan wilayah pusat dan daerah, maupun kesenjangan antar subsektor

74 Dampak Pelaksanaan Program Pengembangan Usaha Agribisnis Pedesaan (Puap) Di Kabupaten Indragiri Hulu 
dengan memberikan fasilitas bantuan modal usaha untuk petani, peternak, pemilik, dan penggarap, buruh tani maupun rumah tangga yang disalurkan melalui Gapoktan (gabungan kelompok tani) sebagai pelaksana PUAP. Keberlanjutan program PUAP ditentukan oleh peningkatan peran strategis dari gapoktan sebagai kelembagaan tani pelaksana PUAP sehingga petani dapat meningkatkan kualitas kehidupannya melalui pengembangan kemampuan dan ketrampilan, meningkatkan skala usaha, menciptakan efisiensi, dan meningkatkan produktivitas.

Realisasi pelaksanaan program PUAP tahun 2008 telah dilaksanakan di 33 propinsi di Indonesia, 386 kabupaten, dan 10.542 desa melalui dana Bantuan Langsung Masyarakat (Pusat Pembiayaan, 2009). Penyaluran dana PUAP melalui gapoktan dengan harapan dapat menjadi kelembagaan ekonomi yang dimiliki dan dikelola oleh petani. Penyaluran dana PUAP difokuskan untuk daerah-daerah yang tertinggal namun memiliki potensi pengembangan agribisnis (Anwar, 2008). Di Propinsi Riau dana PUAP telah disalurkan di 11 kabupaten/kota, salah satunya adalah di Kabupaten Indragiri Hulu yang tersebar pada 9 kecamatan yang terdiri dari 30 gapoktan, dimana masing-masing gapoktan menerima pinjaman bergulir sebanyak Rp 100 juta, (Sekretariat PUAP BPTP Riau, 2009). Untuk lebih jelas mengenai rincian desa penerima dana PUAP periode awal yaitu tahun 2008 dapat dilihat pada tabel berikut:

Tabel 1. Desa Penerima Dana PUAP di Kabupaten Indragiri Hulu tahun 2008

\begin{tabular}{|c|l|c|c|r|}
\hline No & Kecamatan & Jumlah Desa & $\begin{array}{c}\text { Jumlah } \\
\text { Gapoktan }\end{array}$ & Total Anggota \\
\hline 1 & Rengat & 5 & 5 & 436 \\
2 & Rengat Barat & 2 & 2 & 189 \\
3 & Seberida & 1 & 1 & 80 \\
4 & Batang Cenaku & 5 & 5 & 356 \\
5 & Lirik & 2 & 4 & 150 \\
6 & Pasir Penyu & 4 & 1 & 350 \\
7 & Sungai Lala & 1 & 6 & 87 \\
8 & Kelayang & 6 & 4 & 465 \\
9 & Peranap & 4 & 264 \\
\hline
\end{tabular}

Sumber: Dinas Pertanian Kabupaten Indragiri Hulu, 2012

Pada Tabel 1 terlihat bahwa tahun 2008 terdapat 9 kecamatan penerima dana PUAP di Kabupaten Indragiri Hulu, dimana Kecamatan Rengat, Batang Cenaku, dan Kelayang memiliki jumlah gapoktan lebih banyak dibandingkan kecamatan lainnya. Berdasarkan ketentuan, dana PUAP dimanfaatkan untuk 
pengembangan agribisnis pedesaan yang mengarah pada peningkatan perekonomian masyarakat. Dalam upaya mencapai tujuan terbentuknya Lembaga Keuangan Mikro Agribisnis (LKMA), maka diperlukan penilaian kinerja gapoktan penerima dana PUAP, sehingga kinerja gapoktan PUAP yang akan ditransformasi kepada petani dan penerima lainnya dapat memenuhi kriteria yang dipersyaratkan. Program Pengembangan Usaha Agribisnis Perdesaan (PUAP) yang telah dilaksanakan perlu dievaluasi dan merupakan bagian dari proses pembangunan karena sebenarnya telah melekat dengan manajemen pelaksanaan kegiatan PUAP namun hanya terbatas pada masalah administratif kegiatan saja atau tidak kepada evaluasi yang berkaitan dengan substansi pembangunan. Sehingga dalam mengevaluasi dampak pelaksanaan program PUAP perlu dilihat gambaran pelaksanaan PUAP pada gapoktan penerima dana PUAP.

Berdasarkan latar belakang maka tujuan penelitian ini adalah: 1) Mengidentifikasi karakteristik petani anggota gapoktan penerima dana PUAP, 2) Mengetahui pelaksanaan program PUAP pada gapoktan penerima dana PUAP, 3) Menganalisis kinerja gapoktan menurut petani penerima dana PUAP, 4) Menganalisis dampak kegiatan program PUAP terhadap peningkatan pendapatan petani anggota gapoktan. Ruang lingkup yang digunakan adalah penerima dana PUAP merupakan petani anggota gapoktan yang berusahatani perkebunan yang berasal dari kecamatan yang memiliki gapoktan aktif, yaitu Kecamatan Rengat, Batang Cenaku, dan Pasir Penyu. Evaluasi dampak program PUAP dilakukan dengan melihat perubahan pendapatan petani sebelum dan setelah menerima dana PUAP.

\section{METODE PENELITIAN}

Penelitian ini menggunakan metode survei pada 3 kecamatan di Kabupaten Indragiri Hulu yaitu 1 gapoktan di Kecamatan Rengat, 2 gapoktan di Kecamatan Batang Cenaku, dan 1 gapoktan di Kecamatan Pasir Penyu, dengan alasan bahwa di kecamatan-kecamatan tersebut terdapat gapoktan penerima dana BLM PUAP tahun 2008 sebagai tahun awal bergulirnya dana PUAP dan masih aktif hingga sekarang.

Penentuan sampel dilakukan secara stratified purposive sampling, dengan terlebih dahulu menentukan gapoktan yang mewakili kecamatan kemudian diambil sampel penerima dana PUAP, yaitu petani yang berusahatani di sektor 
pertanian tanaman perkebunan. Terdapat 4 gapoktan yang dijadikan sanpel, dimana tiap gapoktan diambil 10 petani sehingga total sampel adalah 40 petani.

Pengumpulan data primer diperoleh melalui wawancara langsung kepada petani sampel dengan berpedoman pada daftar pertanyaan (kuisioner) meliputi identitas penerima dana PUAP yaitu umur, tingkat pendidikan, pengalaman usaha, jumlah anggota keluarga, jenis dan luas lahan, luas dan status kepemilikan lahan. Sedangkan data sekunder meliputi gambaran umum atau keadaan daerah, iklim, luas daerah, jumlah penduduk, tingkat pendidikan dan sumber mata pencaharian penduduk dan data-data yang berhubungan dengan program PUAP, yang diperoleh dari instansi-instansi terkait, seperti Kantor Kecamatan, BPS, penyuluh dan penyelia gapoktan.

1. Identifikasi Karakteristik Petani Anggota Gapoktan

Untuk mengidentifikasi karakteristik petani anggota gapoktan program PUAP dilakukan dengan menggunakan metode statistik deskriptif, yaitu metode untuk mengumpulkan, meringkas, menyajikan, dan mendeskripsikan data sehingga memberikan informasi yang berguna (Nisfiannoor, 2009). Metode ini untuk memberikan gambaran petani meliputi umur, tingkat pendidikan, pengalaman usaha, jumlah anggota keluarga, jenis dan luas lahan, penggunaan dana, dan pengetahuan mengenai kegiatan gapoktan.

2. Pelaksanaan Program PUAP

Untuk mengetahui bagaimana pelaksanaan program PUAP maka digunakan analisis deskriptif meliputi awal berdirinya gapoktan, jumlah anggota, visi, misi, struktur kepengurusan, sarana dan prasarana penunjang yang dimiliki, jumlah pinjaman dan pengembalian, dan permasalahan yang dihadapi gapoktan.

3. Kinerja Gapoktan

Analisis kinerja gapoktan dapat dilakukan dengan Importance Performance Analysis (IPA) dengan terlebih dahulu melakukan uji validitas dan reliabilitas. Pengujian validitas bertujuan untuk menguji sejauhmana ketepatan dan kecermatan alat ukur tertentu dalam melakukan fungsi ukurannya. Semakin tinggi validitas suatu variabel maka akan semakin mengenai sasaran (Wijaya, 2011). Analisis IPA menyatukan pengukuran faktor 
tingkat kinerja (performance) dan tingkat kepentingan (importance) seperti gambar berikut:

\begin{tabular}{l|l}
$\begin{array}{l}\text { Kuadran A } \\
\text { Concentrate here } \\
\text { Fair }\end{array}$ & $\begin{array}{l}\text { Extremely important } \\
\text { Keep up the good work } \\
\text { Excelent }\end{array}$ \\
\hline $\begin{array}{l}\text { Performance } \\
\text { Kow Priority }\end{array}$ & $\begin{array}{c}\text { Performance } \\
\text { Kuadran D } \\
\text { Possible over kill }\end{array}$ \\
& \multicolumn{2}{c}{ Slightly Important }
\end{tabular}

Gambar 1. Importance Performance Analysis (Martilla, dkk, 1977)

Berdasarkan Gambar 1 dapat dijelaskan sebagai berikut:

1. Kuadran A “Concentrate here”, Menunjukkan faktor yang dianggap sangat penting, namun memperlihatkan tingkat kepuasan yang rendah

2. Kuadran B "Keep up the good work", Menunjukkan unsur pokok yang sudah ada dan wajib dipertahankan karena sangat penting dan memuaskan pelanggan

3. Kuadran C "Low priority", Menunjukkan faktor yang kurang penting pengaruhnya dan dianggap kurang memuaskan

4. Kuadran D “Possible over kill”, Menunjukkan faktor yang kurang penting namun pelaksanaan kinerjanya memuaskan

Untuk mendapatkan skor antara nilai kepentingan dan kepuasan maka digunakan Skala Likert, seperti yang terlihat pada tabel berikut:

Tabel 2. Skor nilai Kepentingan dan Kepuasan

\begin{tabular}{|c|c|c|}
\hline Skor/nilai & Tingkat Kepentingan & Tingkat Kepuasan \\
\hline 4 & Sangat penting & Sangat puas \\
\hline 3 & Penting & Puas \\
\hline 2 & Kurang penting & Kurang puas \\
\hline 1 & Tidak penting & Tidak puas \\
\hline
\end{tabular}

Pengukuran kinerja gapoktan PUAP menurut Kementrian Pertanian (2010) dapat dilihat pada tabel berikut:

Tabel 3. Indikator Kinerja Gapoktan PUAP

78 Dampak Pelaksanaan Program Pengembangan Usaha Agribisnis Pedesaan (Puap) Di Kabupaten Indragiri Hulu 


\begin{tabular}{|c|c|c|}
\hline No & Aspek & Indikator \\
\hline 1 & Organisasi & $\begin{array}{l}\text { 1. Memiliki AD/ART } \\
\text { 2. Melakukan pemisahan pengurus dan pengelola LKM- } \\
\text { A } \\
\text { 3. Mempunyai rencana kerja } \\
\text { 4. Menyelenggarakan rapat/pertemuan anggota secara } \\
\text { berkala } \\
\text { 5. Melaksanakan RAT tepat waktu } \\
\text { 6. Memiliki badan hokum }\end{array}$ \\
\hline 2 & $\begin{array}{l}\text { Pengelolaan } \\
\text { dana PUAP }\end{array}$ & $\begin{array}{l}\text { 1. Adanya melakukan sosialisasi program PUAP } \\
\text { 2. Adanya kemudahan persyaratan penerima PUAP } \\
\text { 3. Adanya waktu realisasi pinjaman } \\
\text { 4. Adanya pencatatan dan pembukuan } \\
\text { 5. Adanya analisa kelayakan usaha } \\
\text { 6. Adanya laporan yang dibuat pengurus gapoktan } \\
\text { 7. Adanya pembinaan usaha anggota } \\
\text { 8. Adanya pengawasan dalam pembiayaan } \\
\text { 9. Adanya insentif dan sanksi } \\
\text { 10. Adanya sarana dan prasarana }\end{array}$ \\
\hline 3 & $\begin{array}{l}\text { Usaha } \\
\text { Agribisnis }\end{array}$ & $\begin{array}{l}\text { 1. Mengadakan saprodi pertanian } \\
\text { 2. Adanya peran penyuluh pendamping } \\
\text { 3. Mengadakan kerjasama keuangan } \\
\text { 4. } \text { Pemasaran dilakukan bersama oleh gapoktan }\end{array}$ \\
\hline
\end{tabular}

4.Dampak Program PUAP Terhadap Peningkatan Pendapatan Petani

Pendapatan petani dapat dihitung dengan menggunakan rumus menurut Soekartawi (1995), yaitu $\pi=\mathrm{TR}-\mathrm{RC}$, dimana $\mathrm{TR}=$ total Revenue, dan $\mathrm{TC}=$ total cost. Selanjutnya untuk mengetahui perbedaan tingkat pendapatan petani sebelum dan sesudah adanya program PUAP, dilakukan dengan uji statistik thitung untuk berpasangan (Walpole, 1995). Formulasinya sebagai berikut:

$$
\text { thitung }=\frac{d-d o}{S d / \sqrt{n}}
$$

keterangan: $\mathrm{d}-\mathrm{do}=$ rata-rata pendapatan setelah pinjaman - sebelum pinjaman

$$
\begin{aligned}
\mathrm{Sd} & =\text { standar deviasi } \\
\mathrm{n} & =\text { jumlah observasi } \\
\mathrm{db} & =\text { derajat bebas }
\end{aligned}
$$

Hipotesis yang digunakan adalah:

1. Ho: $1=2$ atau $1-2=0$, Tidak terdapat perbedaan tingkat pendapatan petani sebelum dan setelah program PUAP

2. Hi: $1>2$ atau $1-2>0$, Adanya perbedaan tingkat pendapatan petani sebelum dan setelah program PUAP

dimana, 1 = pendapatan sebelum pinjaman dana PUAP 
2 = pendapatan setelah pinjaman dana PUAP

Kriteria pengujian:

Ho ditolak apabila t-hitung $>\mathrm{t}$-tabel, $\mathrm{db}=\mathrm{n}-1, \mathrm{p}$ value $<\alpha=0,05$

Ho dierima apabila t-hitung $\leq \mathrm{t}$-tabel, $\mathrm{db}=\mathrm{n}-1, \mathrm{p}$ value $>\alpha=0,05$

\section{HASIL DAN PEMBAHASAN}

\section{Karakteristik Petani}

a. Umur

Sebaran umur petani anggota gapoktan penerima dana PUAP diketahui bahwa umur petani berkisar antara 35-44 tahun yakni 50\% dari total sampel dengan rata-rata 43,9 tahun dan masih dalam kategori usia produktif sehingga produktivitas kerja petani cukup tinggi. Lestari (1997) menyatakan bahwa umur seseorang berkaitan dengan tingkat produktivitas kerja. Apabila seseorang berada dalam usia produktif maka produktivitas kerjanya masih dapat ditingkatkan sehingga hasil pekerjaan yang diperoleh semakin banyak dan pendapatan meningkat.

\section{b. Lama Pendidikan}

Sebagian besar petani hanya memiliki jenjang pendidikan rendah pada tingkat SD (65\%), walaupun demikian pada kenyataannya terdapat beberapa petani yang menamatkan pendidikannya sampai ke jenjang SLTP dan SMA. Tingkat pendidikan berkaitan erat dengan kemampuan seseorang untuk memberikan keputusan apakah bekerja atau tidak dalam rangka memperbaiki taraf hidup keluarga. Rendahnya tingkat pendidikan petani menunjukkan bahwa kualitas sumber daya manusia petani tidak memadai di dalam pengembangan agribisnis dan akses kesempatan kerja di luar pertanian.

c. Pengalaman usaha

Pengalaman berusahatani berkisar antara 10-14 tahun (38\%) atau rata-rata 12,7 tahun. Artinya petani cukup memiliki pengalaman dalam menjalankan aktivitas usaha perkebunannya sehingga memiliki pengetahuan yang baik terhadap kelangsungan hidup usahanya.

d. Jumlah anggota keluarga

Jumlah anggota keluarga yang paling dominan adalah 4-5 jiwa (72\%) atau rata-rata 4,5 jiwa. Jumlah anak cenderung besar, karena anak dinilai bukan sebagai asset (investasi), tetapi sebagai sumber faktor produksi (tenaga kerja) untuk menambah pendapatan keluarga. Semakin banyak jumlah tanggungan 
keluarga akan memperkecil pendapatan per kapita, karena dengan tambah anggota keluarga akan menyebabkan biaya pengeluaran semakin meningkat. Hal ini menyebabkan petani makin sulit untuk keluar dari kemiskinan.

e. Jenis dan luas lahan

Luas lahan yang dimiliki petani termasuk lahan sempit yakni 1 ha sebanyak 18 petani (45\%). Lahan merupakan modal utama produksi pertanian di pedesaan. Kurangnya penguasaan sumberdaya lahan pertanian bagi petani menunjukkan adanya indikasi lemahnya akses lahan bagi petani kecil. Sempitnya lahan pertanian mengakibatkan keluaran output hasil pertaniannya juga sedikit dan tidak efisien.

\section{f. Status kepemilikan Lahan}

Kepemilikan lahan bagi petani menjadikan ukuran kemampuan petani terhadap kepemilikan asset lahan pertanian. Berdasarkan wawancara diketahui bawa keseluruhan petani sampel (100\%) menyatakan bahwa lahan pertanian yang digunakan untuk tempat berusahatani adalah kepemilikan sendiri atau pribadi.

2. Pelaksanaan Program PUAP pada Gapoktan Penerima Dana PUAP

Kabupaten Indragiri Hulu memiliki potensi pertanian seperti tanaman pangan, perkebunan, dan hortikultura. Visi dan misi gapoktan pada umumnya adalah Terwujudnya masyarakat tani yang maju dan sejahtera. Tata cara penyaluran BLM PUAP berdasarkan Peraturan Menteri Pertanian No. 01/Gapoktan-TS/III.V/08, yaitu: 1) BLM PUAP disalurkan oleh pihak I (Pejabat pembuat komitmen yang mewakili Departemen Pertanian RI) kepada pihak II (ketua gapoktan) menjadi bantuan modal usaha kepada gapoktan dalam rangka pengembangan usaha agribisnis pedesaan, 2) Pihak II (ketua gapoktan) membuka rekening penampungan dana di bank yang telah ditunjuk, 3) Pihak II (ketua gapoktan) menyalurkan dana kepada anggota sesuai RUB (Rencana Usaha Bersama), melaporkan penyaluran dan penggunaan serta pengembangan pelaksanaan PUAP kepada pihak I sesuai petunjuk teknis.

Struktur kepengurusan organisasi gapoktan terdiri dari ketua, sekretaris dan bendahara, serta adanya seksi unit-unit usaha yang terdiri atas unit produksi, unit saprodi, unit pengolahan, unit permodalan, unit pemasaran dan unit alsintan. Sementara itu kelembagaan unit usaha simpan pinjam yang dipersiapkan menjadi 
LKMA adalah terdiri dari manajer, seksi administrasi, kasir, pembiayaan, dan seksi kolektor.

Pemerintah menunjuk gapoktan sebagai salah satu kelembagaan pertanian dalam mengatur dana PUAP agar dana tersebut dapat bermanfaat bagi anggotanya. Total keseluruhan dana PUAP yang diterima masing-masing gapoktan sebesar Rp. 100.000.000,-. Sebagian besar dana tersebut dialokasikan dalam kegiatan simpan pinjam keperluan produksi atau kegiatan pemasaran hasil dan usaha lainnya. Selain itu dana PUAP juga digunakan untuk penyediaan saprodi seperti pupuk, benih, dan obat-obatan. Jumlah maksimal pinjaman bervariasi, disesuaikan dengan kebutuhan petani. Kisaran pinjaman dana PUAP adalah Rp. 500.000 - Rp. 2.500 .000 untuk pertama kali pinjaman. Jika pengembalian pinjaman petani lancar maka pinjaman berikutnya dinaikkan menjadi kisaran Rp.1.000.000 sampai Rp. 3.000.000.

Cara pengembalian pinjaman bisa dilakukan per minggu ataupun setiap kali panen. Bagi anggota yang mendapatkan musibah (bencana alam, wabah serangan hama dan penyakit, atau gagal panen) pinjaman tetap menjadi tanggungjawab petani dan tidak dikenakan jasa. Jika anggotanya melakukan pembayaran yang sangat lancar, maka gapoktan melalui LKMA akan memberikan penghargaan berupa meningkatan jumlah pinjaman dan atau hadiah, dan jika mengalami keterlambatan dalam pembayaran angsuran yang sudah jatuh tempo selama 3 bulan berturut-turut, maka ketua kelompok tani sebagai penjamin berkewajiban melakukan penagihan secara langsung kepada anggota yang bersangkutan, dan apabila yang bersangkutan masih tidak membayar maka untuk selanjutnya tidak akan diberi pinjaman lagi.

3. Analisis kinerja Gapoktan

Sebelum dilakukan analisis kinerja gapoktan dengan metode Importance Performance Analysis (IPA), terlebih dahulu dilakukan uji validitas dan reliabilitas dari jawaban kuisioner yang diberikan oleh responden penerima dana PUAP. Cara analisisnya adalah dengan menggunakan korelasi Pearson yaitu dengan cara menghitung koefisien korelasi masing-masing nilai pada pertanyaan dengan nilai total pertanyaan tersebut. Selanjutnya koefisien korelasi $r$ dibandingkan dengan $\mathrm{r}$ tabel. Bila $\mathrm{r}$ hitung $>$ dari $\mathrm{r}$ tabel, maka pertanyaan tersebut valid, seperti tabel berikut: 
Tabel 4. Hasil Uji Validitas

\begin{tabular}{|c|c|c|c|}
\hline \multirow{2}{*}{ Variabel } & \multirow{2}{*}{ Indikator } & \multicolumn{2}{|c|}{ Nilai $r$ hitung } \\
\hline & & kepentingan & kepuasan \\
\hline \multirow[t]{6}{*}{ Organisasi } & 7. Memiliki AD/ART & 0,663 & 0,673 \\
\hline & $\begin{array}{l}\text { 8. Melakukan pemisahan pengurus gapoktan dan } \\
\text { pengelola LKMA }\end{array}$ & 0,724 & 0,451 \\
\hline & 9. Mempunyai rencana kerja & 0,663 & 0,598 \\
\hline & $\begin{array}{l}\text { 10. Menyelenggarakan rapat/pertemuan anggota } \\
\text { secara berkala }\end{array}$ & 0,654 & 0,519 \\
\hline & 11. Melaksanakan RAT tepat waktu & 0,676 & 0,476 \\
\hline & 12. Memiliki badan hukum & 0,464 & 0,648 \\
\hline \multirow{10}{*}{$\begin{array}{l}\text { Pengelolaan } \\
\text { dana PUAP }\end{array}$} & 11. sosialisasi program PUAP & 0,552 & 0,578 \\
\hline & 12. kemudahan persyaratan penerima PUAP & 0,687 & 0,445 \\
\hline & 13. waktu realisasi pinjaman & 0,447 & 0,641 \\
\hline & 14. pencatatan dan pembukuan & 0,601 & 0,470 \\
\hline & 15. analisa kelayakan usaha & 0,464 & 0,481 \\
\hline & 16. laporan yang dibuat pengurus gapoktan & 0,438 & 0,641 \\
\hline & 17. pembinaan usaha anggota & 0,531 & 0,456 \\
\hline & 18. pengawasan dalam pembiayaan & 0,745 & 0,658 \\
\hline & 19. insentif dan sanksi & 0,745 & 0,493 \\
\hline & 20. sarana dan prasarana & 0,745 & 0,448 \\
\hline \multirow{4}{*}{$\begin{array}{c}\text { Usaha } \\
\text { Agribisnis }\end{array}$} & 5. Mengadakan saprodi pertanian & 0,440 & 0,673 \\
\hline & 6. Adanya peran penyuluh pendamping & 0,443 & 0,641 \\
\hline & 7. Mengadakan kerjasama keuangan & 0,425 & 0,418 \\
\hline & 8. Pemasaran dilakukan bersama oleh gapoktan & 0,539 & 0,673 \\
\hline
\end{tabular}

Nilai $\mathrm{r}$ tabel $=0,3961(\mathrm{df}=23$, tingkat kepercayaan 95\% $)$

Berdasarkan Tabel 4 bahwa hasil pengujian validitas untuk masing-masing pengukuran tingkat kepentingan dan tingkat kepuasan terhadap seluruh pernyataan lebih besar dari $\mathrm{r}$ tabel pada tingkat kepercayaan 95\% yaitu 0,3961. Hal ini menunjukkan bahwa seluruh pernyataan dalam kuisioner adalah signifikan dan dapat dinyatakan valid.

Pengujian reliabilitas dilakukan dengan menggunakan koefisien Alpha Cronbach memiliki nilai koefisien Alpha Cronbach antara 0,64-0,90, hal ini berarti bahwa kemungkinan terjadinya kesalahan pengukuran dalam kuisioner cukup rendah sehingga penggunaanya dapat diandalkan dan mampu memberikan hasil pengukuran yang konsisten apabila penulis menyebarkan kuisioner secara berulang kali dalam waktu yang berlainan.

Tabel 5. Hasil Uji Reliabilitas

\begin{tabular}{|c|l|c|}
\hline No & \multicolumn{1}{|c|}{ Data } & \multicolumn{1}{|c|}{ 垔. } \\
\hline 1 & Tingkat kepentingan & 0,886 \\
\hline 2 & Tingkat kepuasan & 0,879 \\
\hline
\end{tabular}

Metode Importance Performance Analysis (IPA)

Setelah dilakukan uji validitas dan reliabilitas terhadap jawaban dari kuesioner yang dibagikan kepada petani sampel, langkah selanjutnya adalah 
mengevaluasi kinerja gapoktan dengan menggunakan metode Importance Performance Analysis (IPA). Data tingkat kepentingan dan tingkat kepuasan dalam IPA terlihat pada tabel berikut:

Tabel 6. Data Tingkat Kepentingan dan Tingkat Kepuasan

\begin{tabular}{|c|c|c|c|}
\hline Variabel & Indikator & $\begin{array}{c}\text { Tingkat } \\
\text { kepentingan }\end{array}$ & $\begin{array}{c}\text { Tingkat } \\
\text { kepuasan }\end{array}$ \\
\hline $\begin{array}{c}\text { Organisas } \\
\mathrm{i}\end{array}$ & $\begin{array}{ll}\text { 1. } & \text { Memiliki AD/ART } \\
\text { 2. } & \text { Melakukan pemisahan pengurus gapoktan } \\
& \text { dan pengelola LKMA } \\
\text { 3. } & \text { Mempunyai rencana kerja } \\
\text { 4. } & \text { Menyelenggarakan rapat/pertemuan } \\
\text { anggota secara berkala } \\
\text { 5. Melaksanakan RAT tepat waktu } \\
\text { 6. } \\
\text { Memiliki badan hukum }\end{array}$ & $\begin{array}{c}4 \\
4,04 \\
4 \\
4,04 \\
4,12 \\
4\end{array}$ & $\begin{array}{l}, 24 \\
3,56 \\
2,36 \\
2,04 \\
\\
3,84 \\
1,96\end{array}$ \\
\hline $\begin{array}{l}\text { Pengelola } \\
\text { an dana } \\
\text { PUAP }\end{array}$ & $\begin{array}{l}\text { 1. } \\
\text { 2. kesialisasi program PUAP } \\
\text { 3. } \text { waktu realisasi pinjaman } \\
\text { 4. pencatatan dan pembukuan } \\
\text { 5. analisa kelayakan usaha } \\
\text { 6. laporan yang dibuat pengurus gapoktan } \\
\text { 7. pembinaan usaha anggota } \\
\text { 8. pengawasan dalam pembiayaan } \\
\text { 9. insentif dan sanksi } \\
\text { 10. } \text { sarana dan prasaran }\end{array}$ & $\begin{array}{c}4 \\
4 \\
4 \\
4,12 \\
4,16 \\
4 \\
4,08 \\
4 \\
4,16 \\
4,16\end{array}$ & $\begin{array}{l}3,92 \\
3,88 \\
2,28 \\
3,72 \\
2,08 \\
2,28 \\
2,40 \\
2,24 \\
3,16 \\
2,56\end{array}$ \\
\hline $\begin{array}{c}\text { Usaha } \\
\text { Agribisnis }\end{array}$ & $\begin{array}{l}\text { 1. Gapoktan mengadakan saprodi pertanian } \\
\text { 2. Adanya peran penyuluh pendamping } \\
\text { 3. Gapoktan mengadakan kerjasama keuangan } \\
\text { 4. Pemasaran dilakukan bersama oleh } \\
\text { gapoktan }\end{array}$ & $\begin{array}{l}4,28 \\
4,32 \\
1,80 \\
4,20\end{array}$ & $\begin{array}{l}4,24 \\
2,28 \\
1,76 \\
4,24\end{array}$ \\
\hline & Nilai rata-rata & 3,976 & 2,952 \\
\hline
\end{tabular}

Grafik IPA dibagi menjadi empat kuadran (Gambar 2), dimana indikator yang berkaitan dengan tingkat kepentingan dan tingkat kepuasan dikelompokkan sebagai berikut:

1. Kuadran A: Tingkatkan Kinerja

Pada kuadran A terdapat sepuluh variabel (50\%) yang dianggap penting tetapi dalam kenyataannya indikator-indikator tersebut belum sesuai dengan yang diharapkan (tingkat kepuasan responden masih sangat rendah). Di wilayah ini, gapoktan perlu meningkatkan kinerja dan melakukan perbaikan secara terus menerus agar performance dalam kuadran ini meningkat. Pada aspek organisasi, diketahui variabel gapoktan mempunyai rencana kerja, menyelenggarakan rapat pertemuan anggota, memiliki badan hukum merupakan variabel yang belum optimal. Pada aspek pengelolaan dana PUAP, variabel waktu dan realisasi pinjaman, analisa kelayakan usaha, pelaporan yang 
dibuat pengurus gapoktan, pembinaan usaha anggota dan adanya pengawasan dalam hal pembiayaan merupakan variabel yang dinilai belum optimal. Sebagian petani berpendapat waktu dan realisasi pinjaman sangat tergantung dari kondisi kas keuangan di LKMA. Pada aspek usaha agribisnis variabel adanya peran penyuluh pendamping merupakan variabel yang dinilai belum optimal. Petani berpendapat bahwa penyuluh datang ketika ada kegiatan dari dinas pertanian terkait.

2. Kuadran B: Pertahankan Kinerja

Pada kuadran B terdapat sembilan variabel (45\%) yang dinilai sudah optimal dalam pelaksanaanya. Pada aspek organisasi, variabel gapoktan memiliki AD/ART, melakukan pemisahan pengurus gapoktan dan pengelola LKMA dan gapoktan melaksanakan RAT tepat waktu sudah terlaksana dengan baik sehingga memberikan kepuasan bagi seluruh anggotanya. Pada aspek pengelolaan dana PUAP, variabel sosialisasi program PUAP, kemudahan persyaratan penerima PUAP, pencatatan dan pembukuan, serta insentif dan sanksi merupakan variabel yang dianggap cukup puas oleh petani. Pada aspek usaha agribisnis, variabel gapoktan menyediakan saprodi pertanian dan pemasaran bersama dilakukan oleh gapoktan dinilai penting dan memiliki kinerja yang baik.

3. Kuadran C: Prioritas Rendah

Pada kuadran C terdapat satu variabel (5\%) yaitu gapoktan mengadakan kerjasama keuangan (C3). Pada aspek usaha agribisnis, variabel gapoktan mengadakan kerjasama keuangan dinilai masih belum optimal dan petani sebagian besar berpendapat gapoktan kerjasama dengan lembaga keuangan tidak penting karena akan menimbulkan bunga pinjaman yang lebih besar dan sanksi yang diterapkan akan menjadi lebih berat terhadap petani. Mengingat usaha petani disesuaikan dengan iklim dan pasar serta memiliki resiko yang tinggi. Sebagian besar petani menganggap kerjasama keuangan dengan lembaga lain tidak penting, hal ini mengindikasikan bahwa kesadaran petani akan pentingnya pengembangan modal untuk keberlanjutan organisasi gapoktan masih rendah.

4. Kuadran D : Cenderung Berlebihan 
Pada kuadran D tidak terdapat variabel yang dinilai memiliki tingkat kepentingan rendah dengan tingkat kinerja tinggi. Hal itu dikarenakan petani responden berpendapat sebagian besar variabel-variabel indikator kinerja dianggap penting. Berikut ini adalah gambaran kuadran dari grafik IPA:

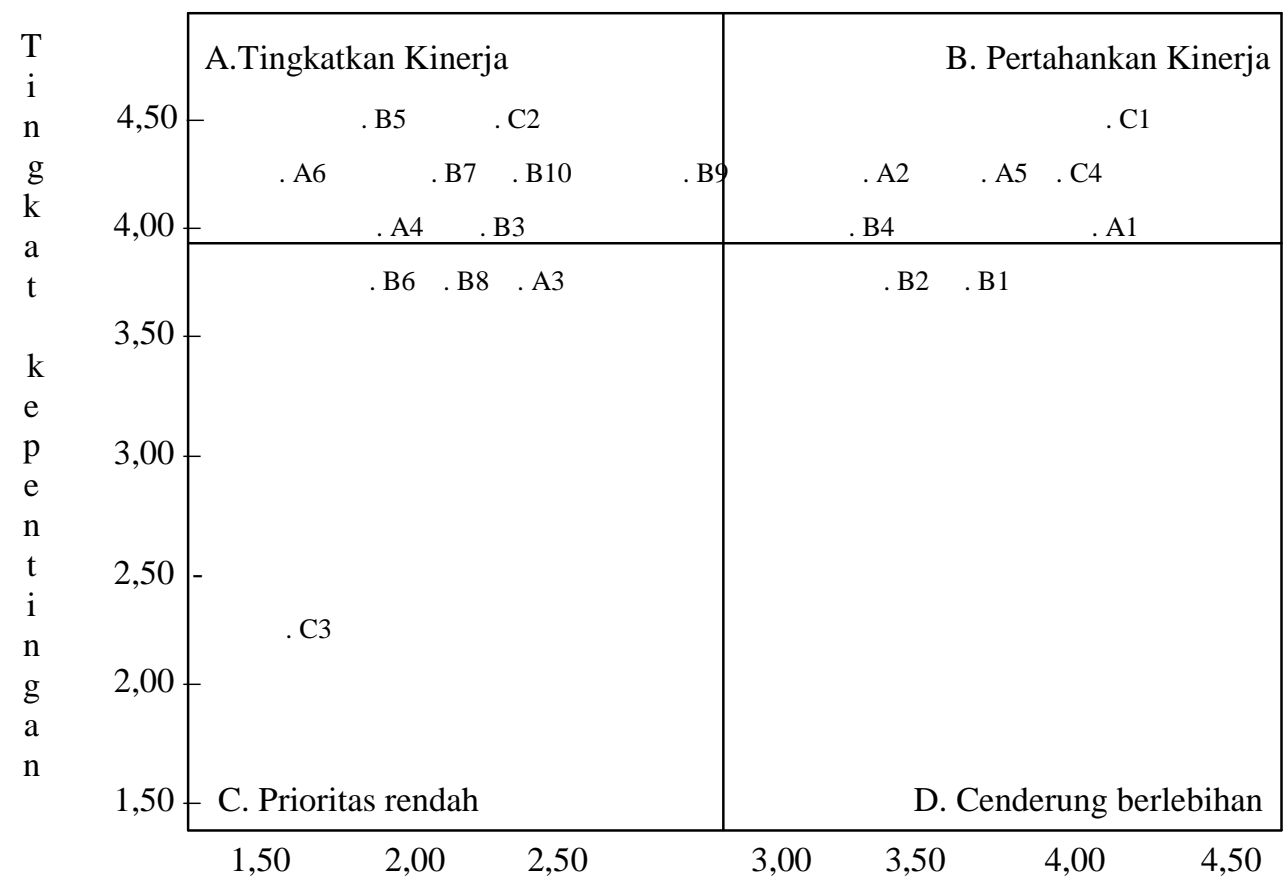

Tingkat kepuasan

Gambar 2. Kuadran Importance Performance Analysis (IPA) terhadap pengukuran kinerja gapoktan

4. Dampak PUAP Terhadap Peningkatan Pendapatan Petani

Hasil uji t-statistik terhadap pendapatan perkapita perbulan sebelum dan setelah program PUAP menunjukkan hasil yang nyata. Hal ini dapat terlihat bahwa nilai p value kurang dari alpha 0,05 . Artinya terdapat perbedaan yang nyata antara pendapatan sebelum dilaksanakan program PUAP dan setelah dilaksanakan program PUAP. Untuk lebih jelas dapat dilihat pada tabel berikut:

Tabel 7. Uji t-statistik Terhadap Pendapatan per Kapita per Bulan Petani

\begin{tabular}{|c|c|c|c|}
\hline \multicolumn{2}{|c|}{ Rata-rata pendapatan (Rp) } & \multirow{2}{*}{ P value } & \multirow{2}{*}{ Keterangan } \\
\hline Sebelum PUAP & Sesudah PUAP & & Berbeda nyata \\
\hline 624.639 & 687.102 & 0,000 & . \\
\hline
\end{tabular}

Berdasarkan Tabel 7 terlihat bahwa pendapatan sebelum dan setelah program PUAP petani penerima adalah berbeda nyata, artinya, pendapatan setelah program PUAP relatif lebih tinggi dibandingkan dengan pendapatan sebelum PUAP. Hal ini disebabkan karena terjadinya inflasi dan juga pertumbuhan 
ekonomi di Kabupaten Indragiri Hulu yang meningkat sehingga berimplikasi kepada peningkatan pendapatan per kapita per bulan bagi petani penerima dana BLM PUAP di Kabupaten Indragiri Hulu.

\section{KESIMPULAN}

1. Karakteristik petani penerima dana BLM PUAP terdiri dari umur dengan ratarata 43,9 tahun, lama pendidikan rata-rata adalah tamat SD, pengalaman usaha rata-rata 12,7 tahun, jumlah anggota keluarga rata-rata 4 jiwa, jenis usaha perkebunan kelapa sawit dengan rata-rata luas lahan 1 ha, dan status kepemilikan lahan umumnya lahan milik sendiri.

2. Pelaksanaan program PUAP bermula pada tahun 2008 dengan 30 gapoktan yang bergabung. Struktur kepengurusan organisasi gapoktan terdiri dari ketua, sekretaris dan bendahara, serta adanya seksi unit-unit usaha. Jumlah maksimal pinjaman awal bervariasi antara Rp. 500.000-Rp. 2.500.000. Cara pengembalian pinjaman bisa dilakukan per minggu, ataupun dibayar setiap kali panen. Bagi anggota yang mendapatkan musibah maka pinjaman tetap menjadi tanggungjawab petani dan tidak dikenakan jasa. Jika anggota melakukan pembayaran sangat lancer akan memberikan penghargaan dan jika anggotanya mengalami keterlambatan dalam pembayaran yang sudah jatuh tempo selama 3 bulan berturut-turut, maka dilakukan penagihan langsung kepada anggota, dan apabila yang bersangkutan masih tidak membayar maka tidak akan diberi pinjaman lagi.

3. Analisis kinerja gapoktan dengan metode Importance-Performance Analysis (IPA) menyatakan bahwa pada kuadran A terdapat sepuluh variabel yang dianggap penting tetapi dalam kenyataannya belum sesuai dengan yang diharapkan (tingkat kepuasan responden masih sangat rendah). Pada kuadran B terdapat sembilan variabel yang dinilai sudah optimal dalam pelaksanaanya. Pada kuadran $\mathrm{C}$ hanya terdapat satu variabel yaitu gapoktan mengadakan kerjasama keuangan (C3) dan pada kuadran D tidak terdapat variabel yang dinilai memiliki tingkat kepentingan rendah dengan tingkat kinerja tinggi.

4. Hasil uji t-statistik terhadap pendapatan perkapita perbulan sebelum dan setelah program PUAP menunjukkan hasil yang nyata. Hal ini dapat terlihat bahwa nilai p value kurang dari alpha 0,05 artinya terdapat perbedaan yang 
nyata antara pendapatan sebelum dilaksanakan program PUAP dan setelah dilaksanakan program PUAP.

\section{SARAN}

1. Pemerintah hendaknya melakukan pembinaan dan pendampingan secara rutin dalam mensosialisasikan pentingnya pengembangan gapoktan sebagai lembaga ekonomi pedesaan untuk kepentingan memajukan kesejahteraan masyarakat dengan meningkatkan modal keswadayaan dan menjembatani hubungan antara gapoktan dengan perbankan, pihak akademisi dan lembaga penelitian untuk penerapan teknologi pertanian.

2. Pemerintah melakukan monitoring dan evaluasi kepada gapoktan secara berkala dan berkelanjutan untuk mengidentifikasi masalah yang muncul dari pelaksanaan kegiatan pinjaman bergulir di lapangan dan kesesuaian antara pelaksanaan kegiatan dengan ketentuan yang berlaku.

3. Mengaktifkan peran penyuluh pendamping gapoktan, karena pengurus dan masyarakat masih memerlukan arahan dalam mengembangkan usaha, yakni dalam hal administrasi maupun budidaya usahatani kepada anggota PUAP secara intensif dan berkelanjutan.

4. Perlu meningkatkan pembinaan, pembimbingan dan pengawasan dalam hal pengajuan pinjaman oleh petani sampai pemanfaatan dan pengembalian dana ke LKMA.

5. Program PUAP selain bantuan modal usaha juga hendaknya juga memperhatikan kemudahan akses penggunaan lahan bagi petani.

\section{DAFTAR PUSTAKA}

Akbar. 2011. Strategi Keberlanjutan Program Pengembangan Usaha Agribisnis Pedesaan (PUAP) Kasus Kabupaten karawang. Tesis. Institut Pertanian Bogor.

Anggraini, Rizqi Sari, Jakoni. 2012. Pemeringkatan Gabungan Kelompok Tani Penerima Dana Pengembangan Usaha Agribisnis Pedesaan di Kabupaten Indragiri Hulu. Balai Pengkajian Teknologi Pertanian (BPTP) Riau. Pekanbaru

Anggriani, Triane Widya. 2012. Analisis Dampak Pelaksanaan Program Pengembangan Usaha Agribisnis Pedesaan (PUAP) Studi Kasus Gapoktan 
Rukun Tani Desa Citapen Kecamatan Ciawi Kabupaten Bogor. Tesis. Magister Perencanaan dan kebijakan Publik. Universitas Indonesia. Jakarta

BPS. 2013. Penduduk Miskin Perkotaan dan Pedesaan. BPS Indonesia. Jakarta

BPS. 2014. Jumlah dan Persentase Penduduk Miskin Indonesia dan Riau. BPS Indonesia, Jakarta

Departemen Pertanian. 2009. Kebijakan Teknis Program Pengembangan Usaha Agribisnis Pedesaan. Jakarta

Dinas Pertanian Kabupaten Indragiri Hulu. 2012. Desa Penerima Dana Program PUAP Tahun 2008. Rengat

Elizabeth, R. 2007. Fenomena Sosiologis Metamorphosis Petani Kearah Keberpihakan Pada Masayarakat Petani Perdesaan Yang Terpinggirkan Terkait Konsep Ekonomi Kerakyatan. Forum Agro Ekonomi (FAE) Vol. 25 PSE-KP. Bogor

Erna, Kadek, I Ketut Kirya, Ni Nyoman Ylianthini. 2012. Pengaruh Dana Pengembangan Usaha Agribisnis Pedesaan Terhadap Pendapatan Anggota Kelompok Simantri. E-Journal Bisma Universitas Pendidikan Ganesha. Volume 2 tahun 2014 (1-8)

Fatma, Pastaliza. 2012. Evaluasi Program Pengembangan Usaha Agribisnis Pedesaan (PUAP) di Kabupaten Solok. Artikel. Magister Perencanaan Pembangunan. Universitas Andalas. Padang

Ginting, J. 2004. Analisis Faktor Penyebab Petani Miskin di Kecamatan Deli Tua. Tesis. Universitas Sumatera Utara. Medan

Ife,Jim, Tesoriero, Frank. 2008. Community Development, Alternatif Pengembangan Masyarakat di Era Globalisasi. Pustaka Pelajar. Yogyakarta.

Ismawan, Bambang. 2000. Pemberdayaan Orang Miskin. Puspaswara. Jakarta

Kartasasmita, Ginandjar. 1996. Pembangunan Untuk Rakyat: Memadukan Pertumbuhan dan Pemerataan. Pustaka CIDESINDO. Jakarta

Kementerian Pertanian, 2009. Pedoman Umum Pengembangan Usaha Agribisnis Perdesaan (PUAP). Deptan Press. Jakarta

Kementrian Pertanian. 2010. Petunjuk Teknis Pemeringkatan (Rating) Gapoktan PUAP Menuju LKM-A. Jakarta

Kuncoro, Mudrajat. 2003. Metode Riset untuk Bisnis dan Ekonomi. Erlangga. Jakarta 
Lastinawati, Endang. 2011. Partisipasi Petani dalam Pelaksanaan Program Pengembangan Usaha Agribisnis Pedesaan (PUAP) di kabupaten Oku. Jurnal Agronobis. Volume 3 No. 5. Sumatera Selatan

Martilla, John A, James John. 1977. Importance Performance Analysis. Journal of Marketing. Volume 41 No. 1 (77-79). American Marketing Asssociation. USA

McNamara, Carter. 1997. A Basic Guide to Program Evaluation. Authenticity Consulting, LLC

Mubyarto. 1989. Pengantar Ekonomi Pertanian. LP3ES. Jakarta

Moeljarto. 1987. Politik Pembangunan: sebuah Analisis, Konsep, arah dan strategi. Pusat Pembiayaan Kementerian Pertanian. 2009. Laporan Hasil Akhir Dukungan PUAP 2008. Tiara Wacana. Yogyakarta

Nasution, Muslimin. 2002. Pengembangan Kelembangan Koperasi Pedesaan untuk Agroindustri. IPB Press. Bogor

Ndraha, Taqliziduhu. 1990. Pembangunan Masyarakat. Rineka Cipta. Jakarta.

Nisfiannoor. 2009. Pengantar Statistik. Salemba Humanika. Jakarta

Nuryana, Mu'man. 2009. Program Evaluation. Departemen Sosial RI. Pusdatin Kesos Kementrian Sosial. Jakarta

Pasaribu, Ali Musa. 2012. Perencanaan dan Evaluasi proyek Agribisnis (Konsep dan Aplikasi) Lily Publisher. Jakarta

Prihartono, M. Koko. 2009. Dampak Program Pengembangan Usaha Agribisnis Pedesaan Terhadap Kinerja Gapoktan dan Pendapatan Anggota Gapoktan. Tesis. Fakultas Ekonomi dan Manajemen. Institut Pertanian Bogor

Pusat Pembiayaan Kementerian Pertanian. 2009. Laporan Hasil Akhir Dukungan PUAP. Jakarta

Ruslan, Kadir. 2011. Pemberitaan Kompas.com “ADB: Penduduk Miskin Indonesia Bertambah". Badan Pusat Statistik Kabupaten Tapanuli Selatan. Sumatera Utara

Sekretaris PUAP BPTP Riau. 2009. Laporan Pelaksanaan PUAP di Propinsi Riau. Balai Pengkajian Teknologi Pertanian Riau. Pekanbaru

Soekartawi. 1995. Analisis Usahatani. UI Press. Jakarta

Soetomo. 2008. Masalah Sosial dan Upaya Pemecahannya. Pustaka Pelajar. Yogyakarta.

Sumarti, Titik, dkk. 2008. Model Pemberdayaan Petani dalam Mewujudkan Desa Mandiri dan Sejahtera (Kajian Kebijakan Sosial Ekonomi tentang

90 Dampak Pelaksanaan Program Pengembangan Usaha Agribisnis Pedesaan (Puap) Di Kabupaten Indragiri Hulu 
Ketahanan Pangan pada Komunitas Desa Rawan Pangan di Jawa). Lembaga Penelitian dan Pengabdian Masyarakat. Institut Pertanian Bogor

Suprapto, Ato. 2008. Eksekutif Bertangan Dingin. Yayasan Agrindo Mandiri. Jakarta

Syahyuti. 2007. Kebijakan Pengembangan Gabungan kelompok tani (Gapoktan) Sebagai Kelembagaan Ekonomi di Pedesaan. Analisis Kebijakan Pertanian. Volume 5 No.1 (15-35) Badan Penelitian dan Pengembangan Pertanian. Kementerian Pertanian. Bogor

Walpole, R.E. 1995. Pengantar Statistik Edisi Ke-3. Gramedia Pustaka Utama. Jakarta

Wedar, Mas. 2011. Konsep Ekonomi Pembangunan. Bahan Ajar Mata Kuliah Perencanaan dalam Pembangunan Ekonomi. Pasca Sarjana. Fakultas Ekonomi Universitas Indonesia. Jakarta

Wijaya, Toni. 2011. Manajemen Kualitas Jasa Desain Servqual, QFD, dan Kano Disertai Contoh Aplikasi dalam Kasus Penelitian. PT. Indeks. Jakarta 